\title{
Klubové organizácie humanitárneho typu: manažment ich služieb a prínos pre spoločnost'
}

Club organizations of humanitarian type: management of their services and benefits for society

\section{Bohumír Krátky, Mária Murray Svidroňová}

Abstract: The aim of the article is to analyse the strategic management of services of a selected international humanitarian organization, which with the help of its members provides emergency assistance around the world. By achieving its goals at the same time, the organization contributes to the fulfilment of the public/general interest. The article responds to a common opinion that non-governmental club-type organizations, which are part of international humanitarian organizations, provide mutually beneficial services, in particular for their members or a close group of people. The main method used is a case study to analyse data from the international humanitarian organization Lions Clubs International. The case study shows not only the ways of strategic management of services provision, but also points to the need and appropriateness to intervene in decisions during the actual implementation of activities and performance of the organization.

Key words: Non-governmental organizations. Strategic management. Lions. Welfare services. Well-being services.

JEL Classification: L31. H44. I39.

Úvod

Neziskový mimovládny sektor ponúka mnohé možnosti na uplatnenie takmer každému. Tento sektor spoločnosti zažil svoj prirodzený a intenzívny vývin za posledné tri desat'ročia (Kuvíková a kol., 2016). Pád socialistického režimu v Česko-Slovensku umožnil realizáciu d'alších možností naplńania ekonomických a sociálnych potrieb. Počiatok, ktorý je možné označit’ aj za formálnu neexistenciu, následne strieda rýchly rozvoj naplnený nadšením, ktoré prináša jeho stabilizáciu a profesionalizáciu. $\mathrm{S}$ otvorením hraníc prišla pre občanov nielen možnost' dozvediet' sa o neziskovom mimovládnom sektore v zahraničí viac, ale aj možnost' 
stat' sa súčast'ou rôznych medzinárodných organizácií. S rozvojom občianskej spoločnosti a neziskového mimovládneho sektora začali v 90. rokoch 20. storočia vznikat' kluby poskytujúce služby členom komunít, ako na Slovensku, tak aj v Českej republike. Jednotlivci, ktorí sa zaujímajú o tieto medzinárodné organizácie mali a stále majú možnost' vybrat' si príslušnost' k medzinárodným organizáciám podl’a ich vízie, účelu a toho, aké plnia poslanie. Jediným obmedzením stat' sa členom takéhoto klubu často býva potreba dostat' pozvánku od iného člena klubu.

Neziskové organizácie - združenia poskytujúce služby (alebo kluby, resp. klubové organizácie poskytujúce služby), ako sú Lions Clubs, Rotary a Kiwanis, vytvárajú priestor, kde sa členovia stretávajú, aby uspokojili svoje záujmy a spoločenské potreby, ako aj riešenie svojich záujmov v komunite (Charles, 1993).

Na prvý pohl'ad by sa tak mohlo zdat', že klubové organizácie poskytujú najmä vzájomne prospešné služby len pre svojich členov či úzku komunitu l'udí. Avšak, rovnako ako mnohé neziskové organizácie, aj kluby poskytujúce služby majú poskytovanie kolektívnych statkov (služieb) zakotvené v poslaní organizácie. Napríklad organizácia Lions Clubs International (d’alej aj „LCI“) uvádza svoje poslanie ako „Umožnit' dobrovol'níkom slúžit’ svojim komunitám, uspokojovat' humanitárne potreby, podporovat' mier a podporovat' medzinárodné porozumenie prostredníctvom klubov Lions.“ (LCI, 2020). Organizácia Rotary International uvádza svoje poslanie zasa nasledovne: „Poskytujeme služby a pomoc, propagujeme integráciu a napomáhame pochopeniu vo svete, dobrej vôli a mieru, prostredníctvom spoločenstva popredných osobností v biznise, profesijných mentorov a komunitných lídrov.“(Rotary, 2019).

Uvedené pre nás predstavuje výzvu, aby sme činnost' medzinárodných organizácií klubového typu predstavili bližšie a analyzovali ich prínos z pohl’adu vzájomnej verzus verejnej prospešnosti, a to prostredníctvom príkladov strategického manažmentu organizácie pri poskytovaní služieb komunitám. Príspevok tak vznikol ako reakcia na bežne sa vyskytujúci názor, že mimovládne neziskové organizácie klubového typu, ktoré sú súčast'ou medzinárodných humanitárnych organizácií, poskytujú vzájomne prospešné služby najmä pre svojich členov či úzku skupinu blízkych l'udí. Ciel’om príspevku je priblížit' strategický manažment služieb vybranej medzinárodnej humanitárnej organizácie, ktorá prostredníctvom svojich členov poskytuje pomoc v núdzi po celom svete a tak dosahuje svoje ciele, čím zároveň prispieva k napíňaniu verejného, resp. všeobecne prospešného záujmu. 


\section{Teoretické východiská}

Ako už bolo uvedené, môže sa zdat', že klubové organizácie poskytujú najmä vzájomne prospešné služby - len pre svojich členov či úzku komunitu l’udí.

Členovia klubov tak slúžia nielen miestnym komunitám, ale spája ich aj vyššie poslanie. Navyše, ak sa na problematiku pozrieme z globálneho hl’adiska, tak hovoríme o státisícoch členov, tzn. aj keby len poskytovali služby v rámci svojich komunít, pri takom počte už môžeme hovorit', že ide o verejný, resp. všeobecne prospešný záujem (Strečanský a kol., 2017). Kto má prospech z neziskových organizácií a filantropie? Je to tretí sektor? Odpoved'ou vo všeobecnosti je, že všetci máme úžitok priamo alebo nepriamo, hmatatel'ne aj nehmotne profitujeme z neziskových nemocníc, múzeí, univerzít, náboženských inštitúcií a sociálnych služieb. Prínosom pre nás je tiež obhajoba verejného záujmu zo strany neziskových organizácií, z ich príspevkov pre našu občiansku spoločnost' a z našej vlastnej dobrovol'nej účasti na ich úsilí (Wolpert, 2002).

Pokial' má byt' organizácia považovaná za dobrovol'nú, účast'v rámci organizácie musí byt' oslobodená od povinnosti alebo nátlaku, to znamená, že musí byt' obsiahnutý zmysluplný stupeň výberu. Organizácie, v ktorých je účast' určená pôvodom (napríklad kmene, rodiny a kasty), právne povinná alebo iným spôsobom vynútitel'ná, sú vylúčené. Organizácie, v ktorých je členstvo požadované, aby mohol byt' prevádzkovaný obchod, alebo profesia aby mohla byt' vykonávaná živnost', môžu byt' považované za dobrovol'né v takom rozsahu, v akom výber profesie a podnikania je sám osebe vecou vol'by. Táto dôležitá črta kombinovaná s požiadavkou na obmedzené rozdelenie zisku slúži na nižšej úrovni ako splnomocnenie na účely verejného záujmu, ked’že organizácie, v ktorých sa jednotlivci slobodne rozhodnú zúčastnit', no od ktorých môžu očakávat' iba obmedzený alebo vôbec žiadny zisk, musia byt' organizáciami, ktoré slúžia na nejaké verejné účely v povedomí tých, ktorí sú v nich zapojení (Salamon, Sokolowski, 2016).

Uvedené znaky spĺn̆a aj vybraná analyzovaná organizácia Lions Club International, ktorá je organizáciou sociálneho zabezpečenia oslobodenou od dane a nie je oprávnená prijímat' alebo vyžadovat' charitatívne dary, podl'a oddielu 501 (c) (4) zákona o vnútorných prímoch národnej agentúry pre výber daní Internal Revenue Service, prijatého Kongresom USA. LCI nie je organizovaná za účelom zisku a je prevádzkovaná výlučne na podporu sociálneho zabezpečenia. Príjmy organizácie nie sú v prospech žiadneho súkromného akcionára alebo jednotlivca. Dary, ktoré prijíma LCI sú príjmami medzinárodnej nadácie Lions Clubs International Foundation, ktorá je verejnou charitatívnou organizáciou oslobodenou od dane 
podl’a 501 (c) (3) zákona o vnútorných prímoch. Z dôvodu globálneho charakteru a štruktúry, LCI eviduje svoju členskú základňu v online adresári, ktorý je prístupný po overení menom a heslom. Po splnení podmienok na vytvorenie klubu, LCI autorizuje klub Lions a pridelí mu identifikačné poradové číslo. Klub nemá právnu subjektivitu, pretože to nie je podmienkou pri vzniku klubu. Členovia klubu rozhodnú, či a akú právnu formu organizácie využijú pri svojej činnosti podl'a príslušných zákonov platných pre lokalitu, v ktorej pôsobia. V Slovenskej republike sú členovia LCI organizovaní v kluboch, ktoré majú právnu formu občianskych združení. Kluby v Českej republike majú právnu formu spolkov.

Charakter služieb poskytovaných neziskovými organizáciami ako je LCI možno upresnit’ definovaním verejných statkov a klubových statkov. Verejné statky sú jedným typom trhového zlyhania. Predstavujú špecifický typ statkov, ktorých kl'účové charakteristiky sú nerivalitnost' spotreby a nevylúčitel’nost' zo spotreby. Klubové statky sú na rozhraní medzi súkromnými a verejnými statkami. Pri poskytovaní niektorých verejných statkov však občania často uprednostňujú konanie nezávisle od vlády. Verejný statok, ktorý sa stáva vylúčitel’ným, je klubový statok (McNutt, 1996). Ekonomická teória klubov predstavuje pokus o vysvetlenie nedostatočnej rovnováhy poskytovania verejných statkov. Vyvoláva zároveň vel’a rôznych sporných otázok, ktoré majú negatívny vplyv na politiku vlády vo verejnom sektore. $\mathrm{V}$ mnohých ohl'adoch klubová činnost' ponúka alternatívu $\mathrm{k}$ centralizovanému vládnemu prerozdel’ovaniu lokálnych verejných statkov. Hlavná charakteristika klubu, faktor vylúčitel'nosti, môže byt' v rozpore s rovným a demokratickým prerozdel'ovaním dobra, ktoré vytvára klub. Na úrovni dobrovol’ných klubov, ktorým sa pôvodne venoval Buchanan (1965), môže teória klubu nadmerne zhodnotit' snahy o dosiahnutie optimálneho počtu členov v klube a maximálnej miery využitia členov klubu.

Medzinárodné organizácie zastrešujúce združenia poskytujúce služby pomáhajú napíňat' ciele svojim členom, čím zároveň spoločne dosahujú deklarované poslanie. Týmto koordinovaným postupom vytvárajú celoplošný vplyv vo vybraných oblastiach pôsobnosti, a to celosvetovo. Takýto postup vyžaduje určenie stratégie umožňujúcej motivovanie a manažovanie dobrovol'níkov, ktorí sú súčast’ou takýchto medzinárodných organizácií a ktorá bude platná vo všetkých častiach sveta, v ktorých organizácia pôsobí.

Strategické riadenie možno interpretovat' ako súbor manažérskych rozhodnutí a akcií organizácie, ktoré možno použit' na ul'ahčenie konkurenčných výhod a dlhodobého lepšieho výkonu v porovnaní s inými organizáciami (Powell, 2001; Wheelen, Hunger, 2004). Strategické riadenie teda zahŕňa niekol'ko kritických krokov, medzi ktoré patrí „,vyhl'adávanie informácií, výber relevantných údajov a ich interpretácia, zostavenie strategického modelu, testovanie a 
uvedenie do praxe“ (Cray, Mallory, 1998). Strategické riadenie sa vo všeobecnosti transformovalo z priemyselnej ekonomiky, ktorá kladie dôraz na produkciu výrobkov ako nevyhnutnost' ekonomického systému, na ekonomiku založenú na vedomostiach, ktorá sa zameriava na výrobu, distribúciu a využitie poznatkov a informácí́. Strategické riadenie ako také pomáha vodcom v neziskových organizáciách pri výbere koncepcie strategického riadenia, ktorá je pre ich organizácie v dnešnej znalostnej ekonomike najvhodnejšia (Kong, 2008). Ciel’om strategického riadenia je znížit' riziko možnej chyby a priviest' organizáciu do situácie, v ktorej môže reagovat' a aktívne pôsobit' na vonkajšie trendy a sily, ako sú konkurencia, zmeny na trhu (predvídat' zmeny, reagovat' na ne, vyvolávat' ich), využívanie vnútorných zdrojov a schopností organizácie (Sedláčková, 2000).

Strategické riadenie prináša značné výhody nielen pre ziskové podniky a vládu, ale aj pre mimovládne organizácie (Allison, Kaye, 2005; Bryson, Roering, 1988; Fowler, 1996). Je to spôsobené tým, že mimovládne organizácie pôsobia $\mathrm{v}$ kontextoch, ktoré sa vyznačujú zložitost'ou, rizikami a finančnou neistotou. K tomu sa pridáva aj Lewis (2003) s tvrdením, že mimovládne organizácie pracujú v nestabilných oblastiach náchylných na konflikty a popri koristníckych alebo „zlyhávajúcich“ štátoch, ktoré môžu na ich prítomnost' pozerat' podozrivo. Podl’a Fowlera (1997) je kl’účovou výzvou pre mimovládne organizácie boj o jasné prepojenie vízie, poslania a úlohy. Je to strategické riadenie, ktoré týmto organizáciám ponúka kompas, proces a stratégiu na zvládnutie transformácie nevyhnutnej v náročných prostrediach, aby mohla zákazníkom poskytovat' vysoko kvalitné služby za nízke náklady (Koteen, 1997). Siciliano (1997) preukázal, že tie mimovládne organizácie, ktoré plánujú, zlepšujú aj svoju sociálnu výkonnost', nielen finančnú. Strategické riadenie môže navyše pomôct' mimovládnym organizáciám nielen efektívne využívat' obmedzené zdroje, ale aj podporovat' efektívnost' a účinnost' programov a projektov (Mara, 2000; McHatton, Bradshaw, Gallagher, Reeves, 2011; Medley, Akan, 2008). To potvrdzuje predpoklad, že vyššia účinnost' riadenia môže viest' k lepšiemu výkonu programu, pretože takáto účinnost’ poskytuje základ na zlepšenie a rast programov a služieb mimovládnych organizácií (Letts, Ryan, Grossman, 1999).

\section{Materiál a metódy skúmania}

Ciel’om príspevku je priblížit' strategický manažment služieb na príklade medzinárodnej humanitárnej organizácie, ktorá cez svojich členov poskytuje pomoc po celom svete a tak dosahuje svoje ciele, čím zároveň prispieva $\mathrm{k}$ napíňaniu verejného, resp. všeobecne prospešného záujmu v komunitách jej pôsobnosti. 
Prostredníctvom prípadovej štúdie poukážeme na strategický manažment vybranej medzinárodnej organizácie a jeho vplyvu na činnost’ členskej základne, ktorá formou kampane počas osláv stého výročia vzniku zvýšila počet poskytnutých služieb a vyzbieraných finančných prostriedkov, pomocou ktorých sú financované projekty členov organizácie.

Podl'a Rubina a Babbieliho je prípadová štúdia idiografickým skúmaním jedinca, rodiny, skupiny, organizácie, obce či spoločnosti a jej hlavným účelom je popis; prijatel'né sú aj pokusy o vysvetlenia (Rubin, Babbie 2001). Ako výskumná metóda je zameraná na štúdium jedného prípadu (single case study) alebo viacerých prípadov (multiple case study), ktoré môže predstavovat' tak jednotlivec, rodina, komunita, organizácia, ako i konkrétna zmena v systéme sociálneho zabezpečenia, nové sociálno-patologické javy, a pod. Podl’a Hendla (2005) ide o zachytenie zložitosti prípadov, o popis vzt'ahov v ich celistvosti.

Podobné chápanie prípadovej štúdie nájdeme aj u iných autorov, napr. Strieženca (1996), Gaburu a Mydlíkovej a kol. (2004), ktorí upozorňujú na to, že pri dodržaní určitej úrovne odbornosti môže táto metóda slúžit’ ako výskumná, ktorá vedecky analyzuje konkrétny prípad.

Prípadová štúdia sa zarad’uje medzi metódy kvalitatívneho výskumu (Allgozzine, Hancock, 2006). Pomocou prípadovej štúdie môže výskumník získat' intenzívny pohl’ad na vybraný spoločenský fenomén. Podl'a Yina je prípadová štúdia aktuálnym prieskumom aktuálneho fenoménu, ktorého skúmanie sa odohráva v jeho prirodzenom prostredí (Yin, 2009). Ďalšími charakteristikami metódy prípadovej štúdie je konkrétne časopriestorové ohraničenie a ohraničenie sociálnym systémom (organizácie, komunity, skupiny), zameranie sa na sledovanie javov, využívanie viacerých primárnych aj sekundárnych zdrojov údajov, napr. analýzu dokumentov (obsahovú analýzu), rozhovory, pozorovanie, dotazníky (Swanborn, 2010).

Ako uvádza Vasil'ová (2013), prvoradou výhodou metódy prípadových štúdií je schopnost' poskytnút' hĺbkovú analýzu fenoménu v určitom kontexte. Výskumník však musí rátat’ aj s nevýhodami tejto metódy, akými sú časová náročnost', problematická externá validita výsledkov a náročná reprodukovatel’nost', ako aj slabá schopnost' zovšeobecnenia výsledkov výskumu pre širšiu populáciu.

Na základe uvedeného sme zvolili metódu prípadovej štúdie, aby sme na vybranej organizácií analyzovali dva prípady strategického manažmentu v praxi. Organizácia bola vybraná zámerne vzhl'adom na dlhoročné pôsobenie jedného z autorov v tejto organizácií, a to aj na riadiacich postoch na národnej úrovni.

Pri skúmaní a analyzovaní uvedenej problematiky sme sa tak opierali o vlastné skúsenosti jedného $\mathrm{z}$ autorov $\mathrm{s}$ pôsobením $\mathrm{v}$ organizácii a teoretické i praktické poznatky, ktoré 
uplatňujeme v rámci vedeckého bádania. Využívali sme publikácie domácich i zahraničných autorov a najmä sme čerpali zo sekundárneho zdroja, ktorým boli dáta medzinárodnej humanitárnej organizácie LCI. Pri spracovaní prípadovej štúdie sme tak využili pozorovanie, obsahovú analýzu dokumentov týkajúcich sa problematiky a empirické poznatky z pôsobenia v LCI na manažérskych pozíciách. Dáta sme získali vd’aka tomu, že vybraná organizácia zhromažd’uje a spracúva informácie v informačných systémoch LCI (LionAccount, MyLion, MyLCI, www.lionsclubs.org), ktoré sú prístupné pre členov cez zabezpečené užívatel'ské kontá. Zber vstupných údajov v systémoch LCI zabezpečuje poverený člen klubu, pričom počet klubov sa celosvetovo pohybuje na úrovni viac ako 46 000. Poverený člen klubu vytvára záznamy o členoch a aktivitách klubu. V procese darovania finančných prostriedkov do LCIF cez webovú stránku alebo aplikáciu sú zaznamenané informácie o darcovi, prijímatel’ovi a využití daru. Súbor zozbieraných údajov tvorí rozsiahlu databázu. V prvom prípade sme pri spracovaní údajov vychádzali zo skutočnosti, že analyzovaná kampaň prebiehala v období 07/2014 - 06/2018, pričom meratel'ným ukazovatel'om bol počet zúčastnených klubov a počet l'udí, ktorým bola poskytnutá služba v sledovanom období. V druhom prípade sme potrebné informácie čerpali z reportov: Kumulatívna podrobná správa o členstve a klube za obdobie 07/2010 - 12/2020, Podrobný prehl'ad servisných činností za obdobie 06/2016 - 12/2020 a z reportu Správa o híbkovej analýze darov za obdobie 06/2013 - 12/2020. Zvolené obdobia boli maximálnymi obdobiami, ktoré bolo možné z databázy exportovat'. Analýzou sekundárnych zdrojov údajov sme získali kumulatívne informácie o počte klubov, počte členov organizácie, počte darcov a výške darovaných finančných zdrojov v období jedného roka k 30. júnu každého kalendárneho roku.

\section{$3 \quad$ Výsledky a diskusia}

V tejto časti prezentujeme výsledky vo forme prípadovej štúdie na organizácii Lions Clubs International $\mathrm{z}$ hl'adiska formovania stratégií tejto organizácie a riadenia poskytovania verejných a všeobecne prospešných služieb, ako aj zabezpečovania zdrojov ich financovania.

Medzinárodná organizácia LCI so sídlom v Oak Brook v štáte Illionis v USA je humanitárno-servisná organizácia, ktorá má najpočetnejšiu členskú základňu s viac ako 1,4 milióna členmi. Víziou organizácie je „byt' globálnym lídrom v humanitárnej a servisnej službe“ (LCI, 2020).

Koordinovanie činností, projektov a služieb v organizácií s takouto početnou členskou základňou si vyžaduje organizačné členenie. Základným stavebným kameňom LCI je klub. Klub je zoskupenie jednotlivcov, ktorí pôsobia v komunite a spoločne pracujú na vybraných 
projektoch či aktivitách. Kluby sú v jednotlivých štátoch zoskupené v dištriktoch (z anglického „District“) tak, aby v jednom dištrikte bol sumárny počet členov v kluboch v rozpätí 1250 až 5 000. V štátoch s väčším počtom členov sú dištrikty zoskupené v multi-dištrikte. Dištrikty a multi-dištrikty sú zoskupené v ústavných oblastiach (z anglického „Constitutional Area“), ktoré pokrývajú všetky oblasti sveta. Tieto oblasti využijeme ako sledovanú oblast’ pri kvantifikácii služieb, darcov a vyzbieraných finančných prostriedkov v d'alšej časti.

\subsection{Strategické riadenie poskytovania služieb}

Jednotlivci (členovia LCI) na základe platnej legislatívy štátu organizujú svoju činnost’ vo vhodných typoch mimovládnych neziskových organizácií tak, aby mali možnost' presadzovat' vlastné záujmy voči samospráve či štátnym organizáciám, pričom toto sa z pohl'adu LCI nevyžadovuje. Všetky aktivity a projekty, ktoré realizujú takéto kluby, sú odsúhlasené členmi a sú dobrovol'né. Pokial' je aktivita alebo projekt, ktorý jednotlivci realizujú v rámci klubu podporovaný LCI, môžu členovia klubu využit' aj financovanie z nadácie Lions Clubs International Foundation (d’alej aj „LCIF“).

LCI na určenie humanitárnych potrieb berie do úvahy celosvetovú situáciu, aktuálne potreby l'udstva a stav planéty Zem, ekologickú krízu, zdravotnícku krízu, ako aj prírodné katastrofy. Takouto stratégiou LCI podnecuje členov k aktivitám, ktoré je možné realizovat' lokálne a ktoré majú plošný, celosvetový význam. Realizácia projektov si vyžaduje nielen personálne zabezpečenie, ktoré vo väčšej miere pokrývajú členovia klubov využitím svojich schopností vo svojom vol’nom čase, ale aj finančné prostriedky. LCI aj vo finančnej oblasti hl’adá spôsoby, ako zabezpečit' financovanie projektov, ktoré kluby realizujú lokálne a ktoré súvisia s oblast'ami, v ktorých chce prispiet' k zlepšeniu celosvetovej situácie. Na celosvetové potreby l'udstva upozorňujú viaceré medzinárodné organizácie. Podl’a Svetovej zdravotníckej organizácie (WHO, 2019):

- 2,2 miliardy l’udí má zhoršený zrak alebo slepotu,

- 1 z 11 l'udí má cukrovku,

- 300000 detí vo veku 0-19 rokov má každý rok diagnostikovanú rakovinu,

- každý deň zomrie 300 l’udí na osýpky,

- do roku 2025 bude polovica svetovej populácie žit’ v oblastiach so žiadnym alebo nedostatočným prístupom $\mathrm{k}$ pitnej vode

Podl'a neziskovej organizácie Food Aid Foundation (2019) 1 z 9 l'udí nemá dostatok jedla na to, aby bol zdravý a aktívny, 821 miliónov l'udí - jeden z deviatich - stále chodí každú noc spat’ nalačno. Organizácia spojených národov (WHO, 2019) upozorňuje, že prírodné katastrofy 
súvisiace s počasím vzrástli za posledných 40 rokov o viac ako $50 \%$. V rámci zdravotníckeho systému i mimo neho existuje podl'a WHO (2019) celkový nedostatok služieb na prevenciu a liečbu neprenosných ochorení, ako sú rakovina, diabetes mellitus, kardiovaskulárne a respiračné ochorenia, či cievna mozgová príhoda.

LCI berie do úvahy výsledky výskumov vyššie uvedených organizácií, a tie majú významnú úlohu pri stanovení ciel'ov. LCI celosvetové výzvy, ktorým aktuálne čelí l’udstvo, zjednocuje v globálnom rámci služieb. Členovia humanitárnej organizácie zabezpečujú vlastné aktivity, projekty, pri ktorých preferujú globálny rámec služieb a poskytujú odporúčané servisné služby, ktoré sa týkajú:

- prevencie ochorenia cukrovky a zlepšenia života l'udí postihnutých touto chorobou,

- prevencie slepoty a zlepšenie kvality života nevidiacich a slabozrakých,

- zabezpečenia prístupu členov komunity k výživným potravinám,

- zabezpečenia udržatel'nej ochrany a obnovy životného prostredia,

- osôb postihnutých detskou rakovinou.

Určenie globálneho rámca služieb je strategickým plánom, ktorý vychádza z hodnôt organizácie LCI. Z tohto pohl'adu je to originál, ktorý nemožno aplikovat' v inej organizácii, nakol'ko je odrazom spôsobu spoločného myslenia v organizácii. Stanovenie globálneho rámca služieb určuje aj podiel medzinárodnej organizácie LCI na verejnom záujme, pretože chce prispiet' k riešeniu celosvetových problémov alebo aspoň k zlepšeniu situácií, ktoré zat’ažujú l'udstvo.

Na zozbieranie údajov o počte vykonaných služieb alebo projektov používa organizácia LCI celosvetovú databázu prístupnú pre členov cez webové rozhranie a cez mobilnú aplikáciu. Členovia organizácie poskytnuté služby po ich vykonaní zaznamenávajú. Služby sa zaznamenávajú pre jednotlivé kluby, pričom je uvedený dátum a počet l’udí, ktorým bola služba poskytnutá, alebo je uvedený objem darovaných finančných prostriedkov. Samotná analýza údajov je náročnou činnost'ou vzhl'adom na ich komplexný charakter a množstvo.

Počet klubov a zároveň počet členov celosvetovo pritom v sledovanom období rástol nasledovne:

- 46385 klubov, 1360125 členov k 30. 6. 2014,

- 46510 klubov, 1377913 členov k 30. 6. 2015, nárast členov o 17788 (1,30 \%),

- 46745 klubov, 1379490 členov k 30. 6. 2016, nárast členov o 1577 (0,11\%),

- 47390 klubov, 1425795 členov k 30. 6. 2017, nárast členov o 46305 (3,35 \%),

- 48240 klubov, 1453294 členov k 30. 6. 2018, nárast členov o 27499 (1,92 \%). 
Kvantifikácia vykonaných služieb, projektov a darov má za ciel' porovnanie dosiahnutých výsledkov s ciel’mi, ktoré organizácia LCI stanovila celosvetovo na určité obdobie.

\section{Príklad 1. „Centennial Service Challenge”}

V roku 2017 LCI oslávila 100. výročie vzniku organizácie. LCI stanovila za formu oslavy poskytnutie služby l'udstvu. LCI vyzvala členov z celého sveta, ktorí sú organizovaní v kluboch, aby sa zúčastňovali špeciálnych iniciatív, programov a podujatí na oslavu 100. výročia. Ciel’om bolo poskytnút' 100 miliónom l’udí službu počas štyroch rokov, presne v období od 1. 7. 2014 do 30. 6. 2018. LCI odporučila služby, ktoré sú zamerané na oblasti ochrany a prevencie zraku, ochrany životného prostredia, zmiernenia hladu a práce s mládežou. Vedenie LCI po prvom roku od spustenia kampane na základe dosiahnutých výsledkov konštatovalo, že stanovený ciel' dosiahnu členovia organizácie skôr, ako bolo predpokladané v stanovenom období, a preto upravila ciel' kampane na 160 miliónov l'udí. LCI v poslednom roku obdobia doplnila výzvu aj na služby zamerané na prevenciu pred ochorením diabetes. V Tabul'ke 1 je uvedený počet klubov, ktoré sa pridali k výzve a zorganizovali vlastné aktivity alebo projekty v jednotlivých oblastiach.

V druhom stĺpci je uvedený počet l’udí, ktorým bola poskytnutá služba v jednotlivých oblastiach globálneho rámca služieb.

Tabul'ka 1 Počet zúčastnených klubov a počet l'udí, ktorým bola poskytnutá služba (2014-2018)

\begin{tabular}{|l|c|c|}
\hline $\begin{array}{c}\text { Oblasti záujmu / „Centennial Service } \\
\text { Challenge” }\end{array}$ & $\begin{array}{c}\text { Počet klubov, ktoré } \\
\text { sa pripojili k výzve }\end{array}$ & $\begin{array}{c}\text { Počet l'udí, ktorým } \\
\text { bola poskytnutá } \\
\text { služba }\end{array}$ \\
\hline Podpora mládeže / Youth & 34235 & 75229717 \\
\hline $\begin{array}{l}\text { Ochrana životného prostredia / } \\
\text { Environment }\end{array}$ & 28076 & 74145179 \\
\hline Ochrana zraku / Vision & 28527 & 37858536 \\
\hline Zmiernenie hladu / Hunger & 28321 & 54956923 \\
\hline Prevencia ochorenia diabetes / Diabetes & 14186 & 6803171 \\
\hline Celkom & & $\mathbf{2 4 8 9 9 3 5 2 6}$ \\
\hline
\end{tabular}

Zdroj: Vlastné spracovanie na základe dát z www.lionsclubs.org

Po skončení stanoveného obdobia oslavy 100. výročia bol ciel' dosiahnutý a počet l'udí, ktorým bola poskytnutá služba, viac ako zdvojnásobený. Služba bola poskytnutá 248993526 l'ud'om. Prevencia ochorenia Diabetes bola doplnená medzi sledované oblasti až v poslednom roku stanoveného obdobia, od 1.7. 2017 do 30. 6. 2018. Z tohto dôvodu je podiel poskytnutých služieb rádovo nižší. Celkovo sa podiel'alo na dosiahnutí týchto výsledkov $72 \%$ klubov, pričom jeden klub sa mohol zapojit' svojimi aktivitami do jednej vybranej oblasti, do viacerých alebo 
aj všetkých oblastí. Táto niekol'koročná stratégia „Centennial Service Challenge“ sa stala základom pre d’alšiu činnost' LCI. Na základe výsledkov LCI vyzvala členov, aby pokračovali v poskytovaní služieb a zvýšili svoj vplyv v komunitách, v ktorých pôsobia. „LCI Forward“ nadväzuje na úspech „Centennial Service Challenge“ a vyzýva členov nad’alej poskytovat’ služby v týchto oblastiach tak, aby boli služby poskytnuté 200 miliónom l’udí každý rok.

\subsection{Strategické riadenie na zabezpečenie financovania}

Realizácia projektov si vyžaduje nielen personálne zabezpečene, ktoré vo väčšej miere pokývajú členovia klubov využitím svojich schopností vo svojom vol'nom čase, ale aj finančné prostriedky. LCI aj vo finančnej oblasti hl'adá spôsoby, ako zabezpečit' financovanie projektov, ktoré kluby realizujú lokálne a ktoré súvisia s oblast'ami, v ktorých chce organizácia prispiet' k zlepšeniu celosvetovej situácie. Vo všeobecnosti členovia klubu majú možnost' využit' na realizáciu projektov viaceré a/alebo kombinované finančné možnosti. Finančnú podporu je možné uskutočnit' na troch úrovniach: klubovej (členovia, fyzické a právnické osoby ako podporovatelia klubu, verejne dostupné zdroje samosprávy a štátu, eurofondy), dištriktnej (po splnení dohodnutých podmienok je možné využit' finančné zdroje z rozpočtu dištriktu) a na úrovni LCI (po splnení podmienok je možné využit' finančné zdroje z nadácie LCIF).

\section{Príklad 2. „Campaign 100“}

V roku 2017 LCI oznámila najambicióznejšiu kapitálovú kampaň s názvom „Campaign 100“. Ciel’om kampane bolo vyzbierat’ 300 miliónov amerických dolárov v období troch rokov, presne v období od 1. 7. 2018 do 30. 6. 2021. Všetky vyzbierané finančné prostriedky boli prijaté do nadácie LCIF, ktorá bola založená v roku 1968. Ciel’om LCIF je podpora projektov klubov LCI, ktoré vo svojich komunitách vytvárajú vplyv prostredníctvom projektov a aktivít $\mathrm{v}$ oblastiach:

- ochrana zraku, úsilie zamerané na zbavenie sveta infekčnej slepoty, znižovanie slepoty, ktorej sa dá vyhnút' a poškodenia zraku, a zlepšenie celkovej kvality života poskytovaním služieb nevidiacim alebo slabozrakým,

- práca s mládežou, služba mládeži prostredníctvom lepšieho prístupu ku kvalitnému vzdelaniu, životne dôležitým zdravotným službám, inkluzívnym sociálnym a rekreačným príležitostiam a programom pozitívneho rozvoja,

- pomoc pri katastrofách, zapojenie sa do pomoci pri katastrofách, príprava a reagovanie na prírodné katastrofy, 
- humanitárne úsilie, sponzorovanie a realizácia programov zameraných na odlišné potreby rizikového a zranitel'ného obyvatel'stva, ktoré sú neprimerane ovplyvnené sociálnymi a ekonomickými faktormi a ktoré si vyžadujú špeciálne služby.

Nadácia LCIF rozlišuje prichádzajúce dary vo forme finančných prostriedkov podl’a toho, od koho prichádzajú a kam idú.

V prípade, že prichádzajú od jednotlivca (jedna osoba, jeden člen), sú označené ako „individuálne dary“, v ostatných prípadoch sú dary označené ako „neindividuálne dary“ pochádzajúce z klubu alebo dištriktu. Darca v čase darovania môže určit’ finančnému daru jeho použitie v LCIF, podl’a toho bude označený ako „obmedzený dar“ alebo „neobmedzený dar“. Obmedzený dar sa posiela priamo do konkrétneho programu, tzn. je účelovo viazaný. Napríklad, ked’ je dar poskytnutý pre program „Sight First“, znamená to, že darca určil len jeden program, do ktorého môžu tieto prostriedky íst’, a tým je program „Sight First““. Neobmedzený dar je možné použit' na akýkol'vek grant alebo program LCIF. LCIF určí, kde je to najviac potrebné. Niekedy sú tieto dary označované aj ako dary, ktoré smerujú do „oblasti najvyššej potreby“. $100 \%$ všetkých darov zaslaných do programov LCIF bez ohl'adu na to, či bolo darcami určené ich použitie, ide na humanitárnu pomoc.

Vedenie LCI počas osláv 100. výročia vyzývalo členov na zabezpečenie finančných darov, ktoré podporovali realizáciu projektov klubov a dištriktov. Kapitálová kampaň „Campaign 100“ nadväzuje na obdobie „Centennial Service Challenge” s ciel'om zabezpečit' dostatok finančných prostriedkov na obdobie „LCI Forward“.

LCI eviduje v celosvetovom databázovom systéme od roku 2012 aj údaje o počte darcov a výške finančných prostriedkov. V tabul'kách 2 a 3 sú uvedené počty darcov a výška finančných prostriedkov pozostávajúca z ,individuálnych“ aj „neindividuálnych“ darov. Za sledované oblasti sme zvolili ústavné oblasti (Constitutional Area) podl’a delenia v LCI. Sekundárne údaje uvedené v jednotlivých poliach tabul'ky predstavujú sumárnu hodnotu všetkých dištriktov a klubov patriacich do sledovanej oblasti v období jedného roka. Takto usporiadané údaje poskytujú informáciu o tom, aký vplyv mali strategické rozhodnutia vedenia LCI na dosiahnutie stanovených ciel'ov. 
Tabul'ka 2 Počet darcov v oblastiach podl'a členenia regiónov v organizácii LCI.

\begin{tabular}{|c|c|c|c|c|c|c|c|c|c|c|}
\hline $\begin{array}{l}\text { Sledovaná oblast' } \\
\text { (Constitutional } \\
\text { Area) }\end{array}$ & $\begin{array}{c}2012- \\
13\end{array}$ & $\begin{array}{c}2013- \\
14\end{array}$ & $\begin{array}{c}2014- \\
15\end{array}$ & $\begin{array}{c}2015- \\
16\end{array}$ & $\begin{array}{c}\text { 2016- } \\
17\end{array}$ & $\begin{array}{c}2017- \\
18\end{array}$ & $\begin{array}{c}2018- \\
19\end{array}$ & $\begin{array}{c}\text { 2019- } \\
20\end{array}$ & $\begin{array}{c}2020- \\
21\end{array}$ & $\begin{array}{l}\text { Počet } \\
\text { darcov }\end{array}$ \\
\hline $\begin{array}{l}\text { U.S. and Affiliates, } \\
\text { Bermuda and } \\
\text { Bahamas (oblast' } \\
\text { 1) }\end{array}$ & 9389 & 10064 & 9297 & 10571 & 12432 & 16669 & 13852 & 13738 & 5159 & 101171 \\
\hline Canada (oblast' 2) & 874 & 903 & 807 & 948 & 926 & 1317 & 1089 & 1458 & 515 & 8837 \\
\hline $\begin{array}{l}\text { South America, } \\
\text { Central America, } \\
\text { Caribbean \& } \\
\text { Mexico (oblast' 3) }\end{array}$ & 1762 & 1757 & 1741 & 1410 & 2416 & 2811 & 2915 & 4020 & 3499 & 22331 \\
\hline Europe (oblast' 4) & 3904 & 3817 & 3927 & 3622 & 4578 & 4983 & 4905 & 5410 & 2217 & 37363 \\
\hline $\begin{array}{l}\text { Orient and } \\
\text { Southeast Asia } \\
\text { (oblast' 5) }\end{array}$ & 43955 & 53246 & 65967 & 75485 & 67776 & 73918 & 89800 & 84277 & 44333 & 598757 \\
\hline $\begin{array}{l}\text { India, South Asia, } \\
\text { Africa* and } \\
\text { Middle East } \\
\text { (oblast' 6) }\end{array}$ & 2150 & 1838 & 4136 & 4622 & 4852 & 6173 & 5362 & 4093 & 2831 & 36057 \\
\hline Africa (oblast' 7) & & & & & & & & 590 & 352 & 942 \\
\hline $\begin{array}{l}\text { Australia, } \\
\text { N.Zealand, Papua } \\
\text { N.Guinea, } \\
\text { Indonesia, } \\
\text { S.Pacific (oblast' 8) }\end{array}$ & 1024 & 1366 & 1275 & 1292 & 1951 & 1847 & 1362 & 1317 & 547 & 11981 \\
\hline $\begin{array}{l}\text { Non-Affiliated } \\
\text { (oblast' 9) }\end{array}$ & 550 & 648 & 807 & 745 & 765 & 1024 & 887 & 859 & 554 & 6839 \\
\hline $\begin{array}{l}\text { International } \\
\text { Centennial Lions } \\
\text { Club (oblast' 10) }\end{array}$ & & & & & 0 & 2 & 3 & 5 & 1 & 11 \\
\hline CELKOM & 63608 & 73639 & 87957 & 98695 & 95696 & 108744 & 120175 & 115767 & 60008 & 824289 \\
\hline
\end{tabular}

Zdroj: vlastné spracovanie na základe dát z mylci.lionsclubs.org.

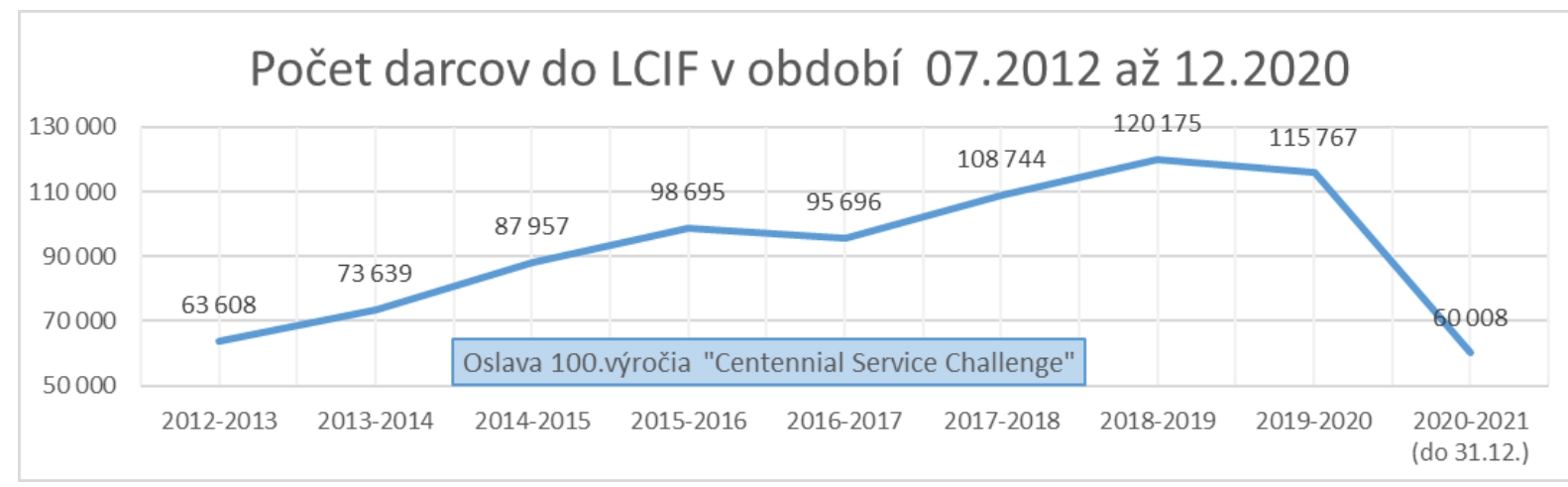

Graf 1 Priebeh nárastu sumárneho počtu darcov pred kapitálovou kampaňou

Zdroj: vlastné spracovanie na základe dát z mylci.lionsclubs.org.

V období osláv 100. výročia (1.7.2014 - 30.6.2018) počet darcov stúpal vo všetkých sledovaných oblastiach, pričom vo všetkých okrem oblasti 8 (Australia, New Zealand, Papua New Guinea, Indonesia, S. Pacific) bol počet darcov najvyšší v poslednom roku osláv, teda v 
období 2017-2018. „Campaign 100“ bola spustená na konci obdobia osláv 100. výročia a toto obdobie sa vyznačovalo plošným rastom počtu darcov. Po prvom roku kapitálovej kampane bol zaznamenaný 10,51 \% nárast darcov, čo celosvetovo predstavuje 11431 darcov. V druhom roku kapitálovej kampane bol zaznamenaný pokles darcov o 3,67 \%, čo celosvetovo predstavovalo o 4408 menej darcov ako v prvom roku 2018-2019. Druhá polovica sledovaného obdobia 2019-2020 (I. polrok roku 2020) bol začiatkom celosvetovej pandémie spôsobenej šírením infekčného ochorenia. Počet darcov 60008 v prvej polovici obdobia 2020-2021 (II. polrok roku 2020), teda v období celosvetovej pandémie, by mohol znamenat' začiatok nárastu počtu darcov a návrat na úroveň prvého roku. 
Tabul'ka 3 Objem finančných darov v amerických dolároch v sledovaných oblastiach

\begin{tabular}{|c|c|c|c|c|c|c|c|c|c|c|c|}
\hline 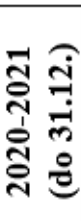 & $\begin{array}{l}2 \\
2 \\
8 \\
0 \\
-1 \\
2 \\
2 \\
n \\
c\end{array}$ & 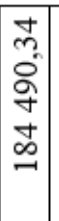 & 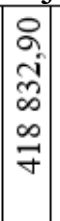 & 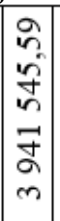 & 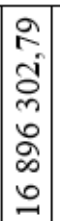 & 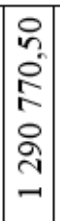 & 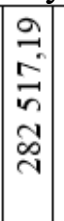 & 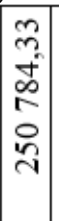 & 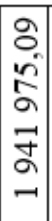 & \begin{tabular}{|c|} 
\\
8 \\
8 \\
0 \\
-1
\end{tabular} & 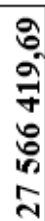 \\
\hline 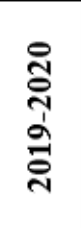 & 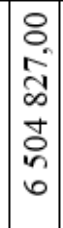 & \begin{tabular}{|c|} 
\\
0 \\
0 \\
0 \\
$\vdots$ \\
0 \\
0 \\
0 \\
0
\end{tabular} & \begin{tabular}{|c|}
0 \\
-1 \\
0 \\
0 \\
0 \\
0 \\
0 \\
-1 \\
-1
\end{tabular} & $\mid \begin{array}{l}0 \\
0 \\
-1 \\
2 \\
2 \\
2 \\
6 \\
+\end{array}$ & 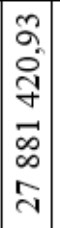 & $\begin{array}{c}\infty \\
\infty \\
i \\
\delta \\
\infty \\
\infty \\
\infty \\
2 \\
\sim\end{array}$ & 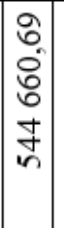 & $\begin{array}{l}n \\
n \\
n \\
\infty \\
\infty \\
g \\
= \\
=\end{array}$ & 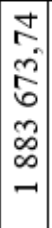 & 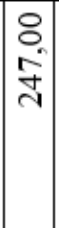 & $\begin{array}{l}\text { in } \\
0 \\
8 \\
0 \\
0 \\
\text { i } \\
\text { I }\end{array}$ \\
\hline 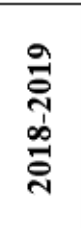 & 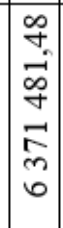 & 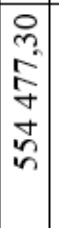 & 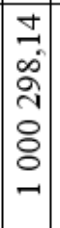 & $\begin{array}{l}0 \\
0 \\
2 \\
5 \\
0 \\
0 \\
2 \\
\gamma\end{array}$ & $\mid \begin{array}{l}1 \\
N \\
0 \\
0 \\
0 \\
\infty \\
0 \\
0 \\
e\end{array}$ & 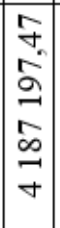 & & 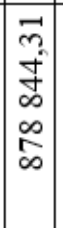 & 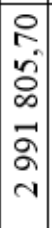 & & 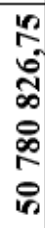 \\
\hline 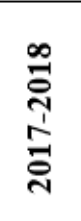 & $\begin{array}{l}0 \\
0 \\
0 \\
0 \\
-1 \\
0 \\
0 \\
0 \\
0\end{array}$ & \begin{tabular}{|l|}
0 \\
$m$ \\
0 \\
0 \\
6 \\
0 \\
0 \\
$f$ \\
\end{tabular} & 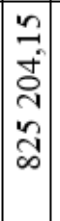 & 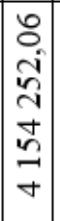 & 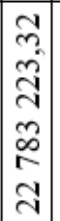 & 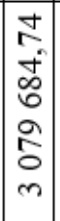 & & 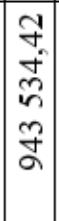 & 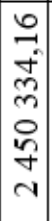 & 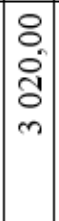 & 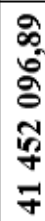 \\
\hline 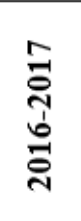 & \begin{tabular}{|l|} 
\\
0 \\
0 \\
0 \\
0 \\
0 \\
0 \\
0 \\
0 \\
in \\
\end{tabular} & 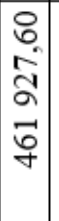 & 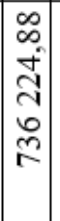 & 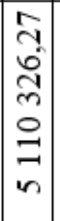 & 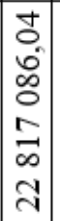 & 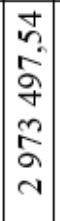 & & 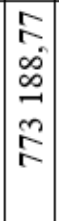 & 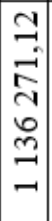 & & 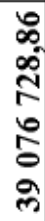 \\
\hline 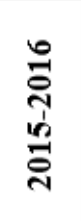 & $\begin{array}{l}\circ \\
\infty \\
\infty \\
2 \\
2 \\
\vec{\sim} \\
\tilde{n} \\
+\end{array}$ & $\begin{array}{l}\infty \\
\infty \\
\infty \\
0 \\
\infty \\
\bar{m} \\
\dot{y}\end{array}$ & 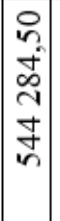 & 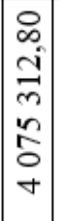 & 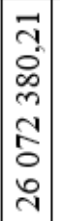 & 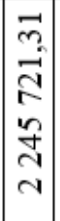 & & $\begin{array}{l}2 \\
6 \\
2 \\
2 \\
2 \\
\vdots \\
\infty \\
\infty\end{array}$ & $\begin{array}{l}m \\
n \\
0 \\
\infty \\
0 \\
\infty \\
\tilde{n}\end{array}$ & & 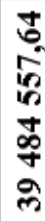 \\
\hline 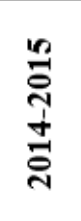 & 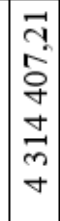 & 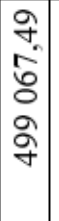 & \begin{tabular}{|c|c}
0 \\
$n$ \\
0 \\
0 \\
$\infty$ \\
$\infty$ \\
$\infty$ \\
$\infty$
\end{tabular} & $\mid \begin{array}{c}0 \\
0 \\
0 \\
0 \\
i \\
0 \\
0 \\
n \\
n\end{array}$ & 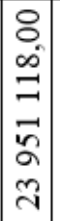 & 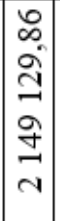 & & 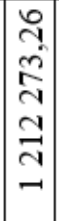 & $\begin{array}{l}\text { P } \\
\vec{a} \\
\stackrel{2}{2} \\
m \\
m \\
m\end{array}$ & & ले \\
\hline 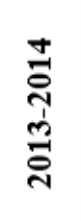 & $\begin{array}{l}m \\
0 \\
0 \\
0 \\
0 \\
\dot{0} \\
\tilde{\sigma} \\
\alpha \\
\dot{v}\end{array}$ & 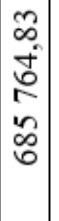 & $\mid \begin{array}{c}0 \\
i \\
0 \\
0 \\
\infty \\
i n \\
0 \\
0 \\
-1\end{array}$ & 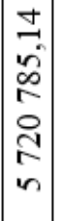 & $\mid \begin{array}{c}2 \\
0 \\
2 \\
\tilde{j} \\
2 \\
\tilde{m} \\
2\end{array}$ & $\mid \begin{array}{c}\infty \\
n \\
0 \\
0 \\
n \\
n \\
\sim \\
\mathcal{H} \\
n \\
\sim\end{array}$ & & 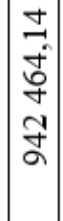 & 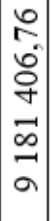 & & \\
\hline 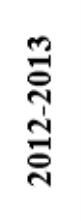 & 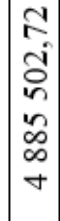 & 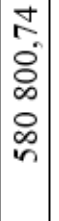 & $\mid \begin{array}{c}8 \\
8 \\
n \\
n \\
n \\
2 \\
8 \\
-1\end{array}$ & $\begin{array}{c}\hat{\sigma} \\
\infty \\
0 \\
\infty \\
\infty \\
\delta \\
\infty \\
\forall\end{array}$ & $\mid \begin{array}{c}m \\
n \\
1 \\
n \\
n \\
n \\
n \\
n \\
=\end{array}$ & $\mid \begin{array}{c}m \\
m \\
2 \\
\tilde{n} \\
\overrightarrow{-} \\
\vec{\sigma} \\
-1\end{array}$ & & $\begin{array}{l}m \\
0 \\
i \\
n \\
z \\
\tilde{z} \\
\tilde{r}\end{array}$ & $\begin{array}{l} \pm \\
n \\
n \\
n \\
\infty \\
n \\
n \\
n\end{array}$ & & \\
\hline $\begin{array}{l}\vec{v} \\
\text { 苛 } \\
0\end{array}$ & $\sqrt{-1}$ & $\mathbf{N}$ & $\infty$ & + & 10 & 6 & 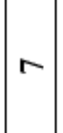 & $\infty$ & $a$ & 이 & \\
\hline
\end{tabular}

Zdroj: Vlastné spracovanie na základe dát z mylci.lionsclubs.org. 


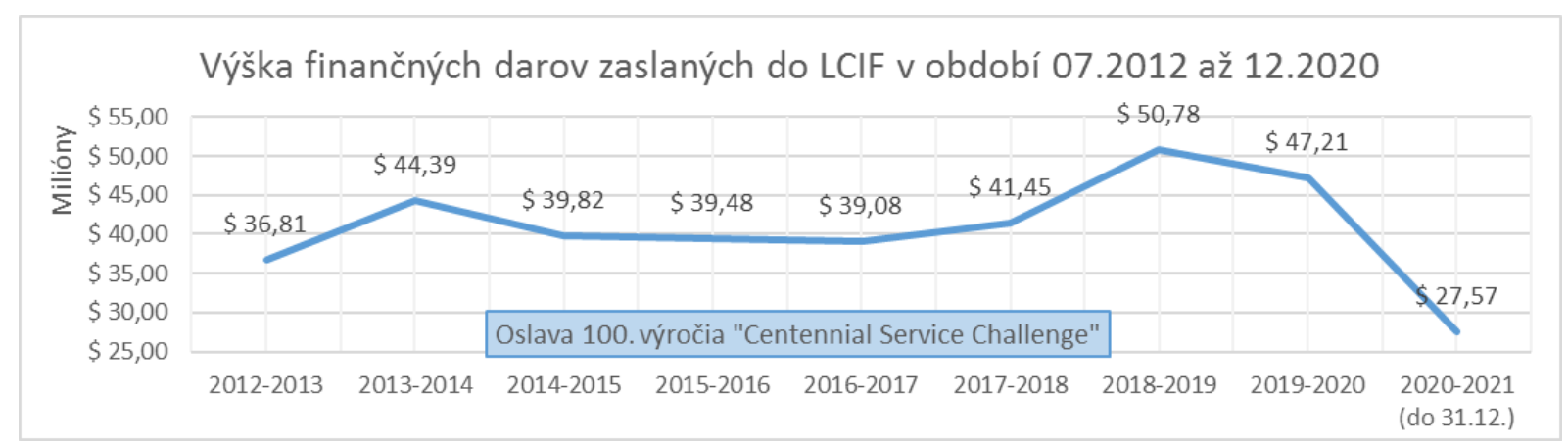

Graf 2 Priebeh nárastu finančných darov po spustení kapitálovej kampane

Zdroj: Vlastné spracovanie na základe dát z mylci.lionsclubs.org.

V období osláv 100. výročia (1. 7. 2014 - 30. 6. 2018) objem finančných prostriedkov zaslaných do LCIF bol v prvých troch rokoch na rovnakej úrovni, pričom až v poslednom roku zaznamenal nárast o 6.08 \%. Počet darcov podl’a grafu 1 bol v tomto období rastúci, čo znamená nižšiu priemernú výšku daru na jedného darcu. Po spustení kapitálovej kampane „Campaign 100“, ktorá bola zameraná na získavanie finančných prostriedkov, stúpol objem finančných prostriedkov o 22,50 \%. Priemerná výška finančného daru na jedného darcu sa zvýšila z 381,19 na 422,56 amerických dolárov. V druhom roku kapitálovej kampane bol zaznamenaný pokles finančných prostriedkov o 7,04 \%, čo celosvetovo predstavovalo zníženie darov o 3574 730,18 amerických dolárov. Priemerná výška finančného daru na jedného darcu sa znížila z 422,56 na 407,77 amerických dolárov. Druhá polovica druhého roku kapitálovej kampane 2019-2020 (I. polrok roku 2020) bola ovplyvnená začiatkom celosvetovej pandémie. Výška darov v prvej polovici obdobia 2020-2021 (II. polrok roku 2020), teda v období celosvetovej pandémie, by mohol znamenat' začiatok nárastu počtu finančných darov.

\subsection{Diskusia}

Na Príklade č. 1 „Centennial Service Challenge” sme poukázali, ako organizácia LCI stanovila typy aktivít aj obdobie, počas ktorého mali prebiehat' aktivity, ako aj konečný meratel'ný ciel' - počet l’udí, ktorým chce organizácia poskytnút' službu. V súlade s víziou, poslaním a ciel'mi LCI vyzvala členskú základňu, aby sa pripojili k oslavám výročia vzniku organizácie a poskytli verejné služby, ktoré sú súčast'ou všeobecne prospešného záujmu v každej komunite. Trvalou požiadavkou organizácie LCI, ktorá by sa dala nazvat’ aj existenčnou v každej organizácii, je obnova a rast členskej základne, ktorá v období osláv narástla. Počet klubov sa zvýšil z 46385 na 48 240, čo predstavuje 4 percentuálne body, a počet členskej základne vzrástol z 1360125 na 1453 294, čo predstavuje 6,85 percentuálnych bodov. LCI už počas osláv svojho stého výročia urobila strategické rozhodnutie a informovala členskú základňu, že za obdobím „Centennial Service Challenge” bude nasledovat’ obdobie „LCI 
Forward“, ktoré nadviaže na úspech „Centennial Service Challenge“ a vyzvala členov nad’alej poskytovat' služby v takom rozsahu, aby LCI poskytla služby 200 miliónom l'udí ročne.

Vyhlásenie kampane „LCI Forward“ a doplnenie oblasti prevencie ochorenia diabetes rok pred ukončením kampane informovala členov o potrebe zmeny a rozvoja aktivít klubov v d’alšom období. Problém spomalenia rozvoja je bežným problémom úspešných spoločností. Hayes (2007) tento úkaz nazýva „pascami úspechu“. Problém nastáva v situácii, ked’ je spoločnost' vel'mi spokojná so svojimi výsledkami a prestane pocit'ovat' potrebu niečo menit', alebo ked' sa vel'mi sústredí na priamy boj s konkurentmi a stráca zo zretel’a celkové zmeny v jej okolí. Organizácia ako taká by sa mala neustále zameriavat' na pokrok, skúmat' trh a analyzovat' svoje vonkajšie aj vnútorné okolie.

Vedenie LCI rozšírilo globálny rámec služieb a upozornilo členov organizácie na možnost' poskytnút' služby súvisiace $\mathrm{s}$ prevenciou ochorenia diabetes. Takýmto zásahom do prebiehajúcej kampane vedenie LCI reagovalo na vonkajšie potreby l'udstva a jej členovia začali poskytovat' služby, ktoré celosvetovo pomôžu znížit' počet l'udí postihnutých týmto ochorením. Rozhodnutie vedenia LCI rozšírit' rámec služieb a oznámit' vyhlásenie novej kampane je v súlade s interpretáciou Powella (2001), Wheelena a Hungera (2004), ktorý súbor takýchto manažérskych rozhodnutí považujú za zabezpečenie dlhodobého lepšieho výkonu.

$\mathrm{Na}$ Príklade č. 2 vidíme, že počet darcov a darovaných finančných prostriedkov stúpol. Strategické rozhodnutie LCI realizovat' finančnú kapitálovú kampaň, ktorá v období troch rokov má zabezpečit' tristo miliónov amerických dolárov, umožní financovanie nových projektov a aktivít klubov. Celosvetová pandemická situácia spôsobená šírením infekčného ochorenia Covid-19, spôsobila obmedzenia pohybu aj mnohé prepúšt’ania či pokles $\mathrm{v}$ podnikatel'ských tržbách, ktoré sa prejavili poklesom počtu darcov, ako aj finančných prostriedkov. Vedenie organizácie LCIF reagovalo na vzniknutú situáciu a v marci 2020 predížilo trvanie kampane o jeden rok, do 30. 06. 2022.

Dedouchová (2001) považuje za najdôležitejšie princípy strategického myslenia variantnost', permanentnost', celosvetový systémový prístup, kreatívny prístup, interdisciplinaritu, vedomú prácu s rizikom, koncentráciu zdrojov a vedomú prácu s časom. Vedenie LCI vo svojich rozhodnutiach zohl’adnilo aktuálnu celosvetovú pandemickú situáciu a vytvorilo pre členov organizácie dlhšie obdobie na dosiahnutie stanoveného ciel'a. V obidvoch príkladoch je potrebné poukázat' aj na skutočnost', že LCI zasiahla do nastavených ciel'ov a prispôsobila ciel'ové parametre (počet l'udí, ktorým bude poskytnutá služba, rozšírenie oblasti rámca služieb a predíženie ukončenia kampane „Campaign 100“) počas samotnej realizácie 
kampaní, čo demonštruje pružnost’ organizácie, celosvetový prístup a prácu s časom pri aktualizácii stratégií.

Dôležitost' strategického manažmentu, jeho kontinuálne vytváranie a prispôsobovanie zdôrazňujú aj Dobson, Starkey a Richards (2004), ktorí preferujú dva základné názory na stratégiu. V prvom stotožňujú pojem stratégia s dlhodobým plánom. Druhý prístup je orientovaný skôr na ad hoc reakcie na zmeny v podnikatel'skom prostredí. Stratégiu je tak potrebné nepretržite vytvárat' a modifikovat'. Prvý prístup je vhodnejší v menej dynamickom a druhý prístup vo viac dynamickom prostredí.

V súlade s Craym a Malloryom (1998) uvedené príklady poukazujú na to, že strategický manažment služieb v LCI zahŕňa kroky: prehl'adávanie prostredia s informáciami, výber relevantných údajov, interpretácia údajov a následné uvedenie do praxe.

\section{Záver}

Ciel’om príspevku bolo priblížit' strategický manažmentu služieb Lions Clubs International, ktorá pomocou svojich členov poskytuje pomoc v núdzi po celom svete a tak dosahuje svoje ciele, čím zároveň prispieva $\mathrm{k}$ napíňaniu verejného, resp. všeobecne prospešného záujmu. Téma klubových statkov a ich dôležitosti stále stojí na okraji záujmu. Skúmaná organizácia LCI poskytuje služby, ktoré zabezpečujú členovia mimovládnych neziskových organizácií - členovia klubov, pričom členovia klubov prioritne nespotrebovávajú tieto služby, ale ich poskytujú verejne a bezplatne komunitám vo svojom okolí, čím celosvetovú stratégiu uplatňujú lokálne.

Kluby sa pri výbere zameriavajú na potreby v komunitách, alebo na dištriktnej úrovni spoločne na potreby v krajinách. Takýmto spôsobom sledovaná organizácia zvláda vel'ké rozdiely, ktoré sú v krajinách po celom svete. Tieto informácie sú pre členov možnost', ako sa zapojit' do činnosti v komunitách a tak prispiet' aj k riešeniu globálnych problémov. Členovia klubov nemusia realizovat' vlastné prieskumy či tvorit' vlastné stratégie: stačí, ak sa inšpirujú odporúčaniami LCI. Pri realizácií odporúčaných aktivít z globálneho rámca služieb členovia klubu zároveň napíňajú myšlienku „mysli globálne, konaj lokálne“.

$\mathrm{Na}$ záver je dôležité poukázat' na to, že strategický manažment služieb LCI je medzinárodný a centrálny, pričom výber činností a projektov, ktoré kluby realizujú, je na rozhodnutí ich členov. Vedenie LCI pri tvorbe globálneho rámca služieb využíva globálne informácie, ktoré predstavujú celosvetové aktuálne problémy. 
Grantová podpora: Príspevok bol podporený z prostriedkov grantovej agentúry APVV v rámci projektu Behaviorálne intervencie $\mathrm{v}$ miestnej samospráve: zvyšovanie účinnosti miestnych verejných politík [APVV-18-0435].

\section{Zoznam použitej literatúry}

[1] Allgozzine, B., \& Hancock, D. R. (2006). Doing case study research: a practical guide for beginning researchers [Výskum prípadových štúdií: praktický sprievodca pre začínajúcich výskumných pracovníkov]. New York, NY: Teachers College Press.

[2] Allison, M., \& Kaye, J. (2005). Strategic planning for nonprofit organizations: A practical guide and workbook (2nd ed.) [Strategické plánovanie pre neziskové organizácie: Praktický sprievodca a pracovný zošit]. Hoboken, NJ: Wiley.

[3] Bryson, J. M., \& Roering, W. (1988). Initiation of strategic planning by governments [Zahájenie strategického plánovania vládami]. Public Administration Review, 48(6), 9951004.

[4] Buchanan, J. M. (1965). An economic theory of clubs [Ekonomická teória klubov]. Economica, 32(125), 1-14.

[5] Cray, D., \& Mallory, G.R. (1998). Making Sense of Managing Culture [Zmysluplnost' riadenia kultúry]. London, UK: International Thomson.

[6] Deduchová, M. (2001). Strategie podniku. Praha, CZ: CH Beck, 2001.

[7] Dobson, P., Starkey, K., \& Richards, J. (2004). Strategic management: issues and cases [Strategické riadenie: problémy a prípady]. Hoboken, NJ: Wiley-Blackwell.

[8] Food Aid Foundation. (2019). Hunger Map 2019 [Mapa hladu 2019]. Dostupné na: https://www.foodaidfoundation.org/world-hunger-statistics.html

[9] Fowler, A. (1996). Demonstrating NGO performance: Problems and possibilities [Demonštrovanie výkonu mimovládnych organizácií: Problémy a možnosti]. Development in Practice, 6(1), 58-65.

[10]Fowler, A. (1997). Striking a balance: A guide to enhancing the effectiveness of nonGovernmental organizations in international development [Dosiahnutie rovnováhy: Sprievodca zvyšovaním efektívnosti mimovládnych organizácií v medzinárodnom rozvoji]. London, Uk: Earthscan Publications.

[11] Gabura, J., \& Mydlíková, E. (2004). Vedenie sociálneho prípadu. Bratislava, SK: ASSP.

[12] Hayes, J. (2010). The theory and practice of change management [Teória a prax riadenia zmien]. New York, NY: Palgrave Macmillan. 
[13]Hendl, J. (2005). Kvalitativní výzkum. Základní metody a aplikace. Praha, CZ: Portál.

[14]Charles, J. A. (1993). Service Clubs in American Society: Rotary, Kiwanis, and Lions [Servisné kluby v americkej spoločnosti: Rotary, Kiwanis a Lions]. Urbana and Chicago, IL: University of Illinois Press.

[15]Kong, E. (2008). The development of strategic management in the non-profit context: Intellectual capital in social service non-profit organizations [Rozvoj strategického riadenia v neziskovom kontexte: Intelektuálny kapitál v neziskových organizáciách poskytujúcich sociálne služby]. International Journal of Management Reviews, 10(3), 281-299. doi: https://doi.org/10.1111/j.1468-2370.2007.00224.x

[16] Koteen, J. (1997). Strategic management in public and nonprofit organizations: Managing public concerns in an era of limits [Strategické riadenie vo verejných a neziskových organizáciách: Správa verejných záujmov v ére limitov]. Westport, CT: Praeger.

[17]Kuvíková, H., Murray Svidroňová, M., \& Gondášová, L. (2016). Poskytovanie služieb bývania mimovládnym neziskovým sektorom. Ekonomika a spoločnost', 16(2), 181-190.

[18]Letts, C. W., Ryan, W. P., \& Grossman, A. (1999). High performance nonprofit organizations: Managing upstream for greater impact [Vysokovýkonné neziskové organizácie: Riadenie dodávatel'ského ret’azca s väčším dopadom]. New York, NY: John Wiley.

[19]Lewis, D. (2003). Theorizing the organization and management of non-governmental development organizations: Towards a composite approach [Teorizácia organizácie a riadenia mimovládnych rozvojových organizácií: smerom k zloženému prístupu]. Public Management Review, 5(3), 325-344. doi: https://doi.org/10.1080/1471903032000146937

[20]Lions Clubs International. (2020). Mission and History [Misia a história]. Dostupné na stránke Lions Clubs International: https://www.lionsclubs.org/en/discover-ourclubs/mission-and-history

[21] Mara, C. M. (2000). A strategic planning process for a small nonprofit organization: A hospice example [Proces strategického plánovania pre malú neziskovú organizáciu: príklad hospicu]. Nonprofit Management and Leadership, 11(2), 211-223. doi: https://doi.org/10.1002/nml.11206

[22] McHatton, P. A., Bradshaw, W., Gallagher, P. A., \& Reeves, R. (2011). Results from a strategic planning process: Benefits for a nonprofit organization [Výsledky procesu strategického plánovania: Výhody pre neziskovú organizáciu]. Nonprofit Management and Leadership, 22(2), 233-249. doi: https://doi.org/10.1002/nml.20051 
[23]McNutt, P. (1996). The Economics of Public Choice [Ekonomika verejnej vol'by]. Chaltenham, UK: Edward Elgar.

[24]Medley, B. C., \& Akan, O. H. (2008). Creating positive change in community organizations: A case for rediscovering Lewin [Vytvorenie pozitívnej zmeny $\mathrm{v}$ komunitných organizáciách: dôvod pre znovuobjavenie Lewina]. Nonprofit Management and Leadership, 18(4), 485-496. doi: https://doi.org/10.1002/nml.199

[25]Powell, T. C. (2001). Competitive advantage: logical and philosophical considerations [Konkurenčná výhoda: logické a filozofické úvahy]. Strategic Management Journal, 22(9), 875-888. doi: https://doi.org/10.1002/smj.173

[26]Rotary International. (2019). Our mission [Naša misia]. Dostupné na: https://www.rotary.org/en/about-rotary

[27]Rubin, A., \& Babbie, E. (2001). Research methods for social work [Metódy výskumu sociálnej práce]. Belmont, TN: Wadsworth / Thomson Learning.

[28] Salamon, L. M., \& Sokolowski, S. W. (2016). Beyond nonprofits: Re-conceptualizing the third sector [Okrem neziskových organizácií: Opätovná koncepcia tretieho sektoru]. VOLUNTAS: International Journal of Voluntary and Nonprofit Organizations, 27(4), 1515-1545. doi: 10.1007/s11266-016-9726-Z

[29] Sedláčková, H. (2000) Strategická analýza. 1. vyd. Praha, CZ: C. H. Beck.

[30] Siciliano, J. I. (1997). The relationship between formal Planning and performance in non profit organizations [Vzt’ah medzi formálnym plánovaním a výkonnost’ou v neziskových organizáciách]. Non Profit Management and Leadership, 7(4), 387-403. doi: https://doi.org/10.1002/nml.4130070405

[31] Stiglitz, J. E. (1997). Ekonomie veřejného sektoru. Praha, CZ: Grada Publishing.

[32] Strečanský, B., Bútora, M., Andrejkovič, M., Guštafík, P., Miková, K., Murray Svidroňová, M., Bútorová, Z., Ondrušek, D., Fialová, Z., Pauliniová, Z., Mesežnikov, G. \& Smieška, B. (2017). Občianska spoločnost’ na Slovensku: krízy, križovatky, výzvy. Bratislava, SK: Inštitút pre verejné otázky.

[33] Strieženec, Š. (1996). Slovník sociálneho pracovníka. Trnava, SK: AD.

[34] Swanborn, P. G. (2010). Case Study Research: What, Why and How? [Výskum prípadových štúdií: Čo, prečo a ako?]. London, UK: SAGE.

[35] Vasil'ová, M. (2013). Využitie prípadových štúdií ako výskumnej metódy v marketingu: Using case studies as a research method in marketing. Vedecké state Obchodnej fakulty 2013. Bratislava, SK: Vydavatel'stvo EKONÓM. 
[36] Wheelen, T. L., \& Hunger, J. D. (2004). Strategic Management and Business Policy [Strategické riadenie a obchodná politika]. Englewood Cliffs, NJ: Prentice Education.

[37] Wolpert, J. (2002). The distributional impacts of nonprofits and philanthropy Distribučné dopady neziskových organizácií a filantropia]. In P. Flynn, \& V. A. Hodkinson (eds) Measuring the Impact of the Nonprofit Sector [Meranie dopadu neziskového sektoru]. (pp. 121-136). Boston, MA: Springer.

[38] World Health Organization. (2019). WHO Data collections [Zbierky dát WHO]. Dostupné na: https://www.who.int/data/collections

[39] Yin, R. K. (2009). Case Study Research. Design and Methods [Výskum prípadových štúdií. Dizajn a metódy]. London, UK: Sage Publications.

Adresa autorov: Ing. Bohumír Krátky, MBA., Katedra verejnej ekonomiky a regionálneho rozvoja, Ekonomická fakulta Univerzity Mateja Bela, Tajovského 10, 97590 Banská Bystrica, Slovenská republika, bohumir.kratky@student.umb.sk

doc. Ing. Mária Murray Svidroňová, PhD., Katedra verejnej ekonomiky a regionálneho rozvoja, Ekonomická fakulta Univerzity Mateja Bela, Tajovského 10, 97590 Banská Bystrica, Slovenská republika, maria.murraysvidronova@umb.sk 